INTERNATIONAL MONETARY FUND

\title{
Macrofinancial
}

\section{Causes of Optimism \\ in Growth Forecasts}

Yan Carrière-Swallow and José Marzluf

WP/21/275

2021

November

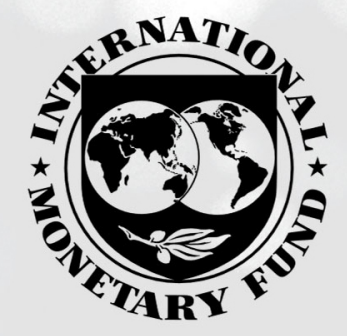


(c) 2021 International Monetary Fund

\title{
Macrofinancial Causes of Optimism in Growth Forecasts WP $/ 21 / 275$
}

Authors: Yan Carrière-Swallow and José Marzluf *

Authorized for publication by Martin Čihák

IMF Working Papers describe research in progress by the author(s) and are published to elicit comments and to encourage debate. The views expressed in IMF Working Papers are those of the author(s) and do not necessarily represent the views of the IMF, its Executive Board, or IMF management.

\begin{abstract}
We analyze the causes of the apparent bias towards optimism in growth forecasts underpinning the design of IMF-supported programs, which has been documented in the literature. We find that financial variables observable to forecasters are strong predictors of growth forecast errors. The greater the expansion of the credit-to-GDP gap in the years preceding a program, the greater its over-optimism about growth over the next two years. This result is strongest among forecasts that were most optimistic, where errors are also increasing in the economy's degree of liability dollarization. We find that the inefficient use of financial information applies to growth forecasts more broadly, including the IMF's forecasts in the World Economic Outlook and those produced by professional forecasters compiled by Consensus Economics. We conclude that improved macrofinancial analysis represents a promising avenue for reducing over-optimism in growth forecasts.
\end{abstract}

\begin{tabular}{|l|l|}
\hline JEL Classification Numbers: & C53, E23, F33, F37 \\
\hline Keywords: & $\begin{array}{l}\text { Macroeconomic forecasting; Financial markets and the } \\
\text { macroeconomy; Credit growth }\end{array}$ \\
\hline Author's E-Mail Address: & ycswallow@imf.org; imarzluf@imf.org \\
\hline
\end{tabular}

\footnotetext{
* We thank Martin Čihák, Atish Rex Ghosh, Divya Kirti, Paolo Mauro, Flavien Moreau, Francesco Luna, Roberto Perrelli, Jiří Podpiera, Yurii Sholomytskyi, Fabián Valencia, Mengxue Wang, Tim Willems, and seminar participants at the IMF's Emerging Markets Forum and the IMF's SPR Macrofinancial Unit for their valuable comments. We also thank Plamen lossifov and Pavel Lukyantsau for generously sharing data. Remaining errors are our own.
} 


\section{INTRODUCTION}

An important function of the International Monetary Fund (IMF) is to assist member countries in implementing macroeconomic programs designed to smooth their external adjustment, which usually involves the disbursement of financing tranches as policy conditionality is met. While assessing the success of these programs is a multi-dimensional exercise, an important backbone of a successful and credible program is a realistic set of projections for macroeconomic variables such as output and inflation. Previous literature has evaluated the IMF's program forecasts for accuracy, bias and efficiency, with many finding evidence of over-optimism (e.g. Kim and others 2021). Over-optimism has been found to be most significant in samples of large programs (Musso and Phillips 2002), at longer horizons (Ho and Mauro 2016), and when planned policy adjustments were large (Ismail, Perrelli, and Yang 2020). ${ }^{1}$ Over-optimism in growth forecasts is problematic not only because it can undermine the calibration of macroeconomic policies, but also because it may itself cause future recessions by incentivizing the accumulation of public and private debt (Beaudry and Willems 2021).

Figure 1 shows forecasts and outturns for real GDP growth surrounding the approval of IMF-supported programs. Over-optimism is a feature of the median forecast made both in the context of programs implemented in advanced and emerging economies and those programs made available on concessional terms to the IMF's lower-income member countries. ${ }^{2}$ Across 306 programs approved from 2000 to 2019, the mean annual growth rate over the next two years ended up being 0.76 percentage points lower than initially forecast at the time of the program request. That is, the level of output two years hence ended up being 1.5 percentage points lower than forecast.

Over-optimism of growth forecasts may reflect several factors, which are likely to be sample specific. Growth is affected by shocks that could not have been foreseen by the forecaster, such as a fall in the world price of an exported commodity, the emergence of a civil conflict, or a global financial crisis (IMF 2019). To the extent that these unanticipated shocks do not have a zero mean in a particular sample, this can give rise to a biased forecast. Growth forecasts may also err because they are inefficient, in the sense that the forecaster did not make full use of the information that was available at the time of the forecast. ${ }^{3}$ This can arise because a planned policy change ends up not having the expected impact on future growth, a planned policy change does not get implemented, or alternatively because the forecaster did not correctly model the relationship between the past and future evolution of observable variables.

We present forecast efficiency tests that check whether ex post growth forecast errors are correlated with characteristics of the financial system that were observable when a program was designed. Methodologically, our approach is similar to Blanchard and Leigh (2013), who document that planned fiscal consolidations were a good predictor of growth over-optimism in IMF-supported programs in the euro zone

\footnotetext{
${ }^{1}$ A condensed version of Ismail, Perrelli, and Yang (2020) was included as part of the IMF's most recent Review of Conditionality (IMF 2019), which provided a wholistic evaluation of programs approved between 2011 and 2017 . Kim and others (2021) is a background paper for the IMF's Independent Evaluation Office report on "Growth and Adjustment in IMF-Supported Programs".

2 Emerging and advanced economies undertake programs financed by resources from the IMF's General Resources Account (GRA), while low-income members have access to concessional resources from the Poverty Reduction and Growth Trust (PRGT). The latter are governed by a different set of rules that allow, inter alia, for needed policy adjustments to take place more gradually.

${ }^{3} \mathrm{~A}$ biased forecast is considered inefficient if the past bias predicts future errors. If the source of the sample bias is the realization of transitory shocks in the sample period, past bias may or may not predict future forecast errors.
} 
Figure 1. Evolution of Real Output Growth Surrounding the Approval of IMF-Supported Programs

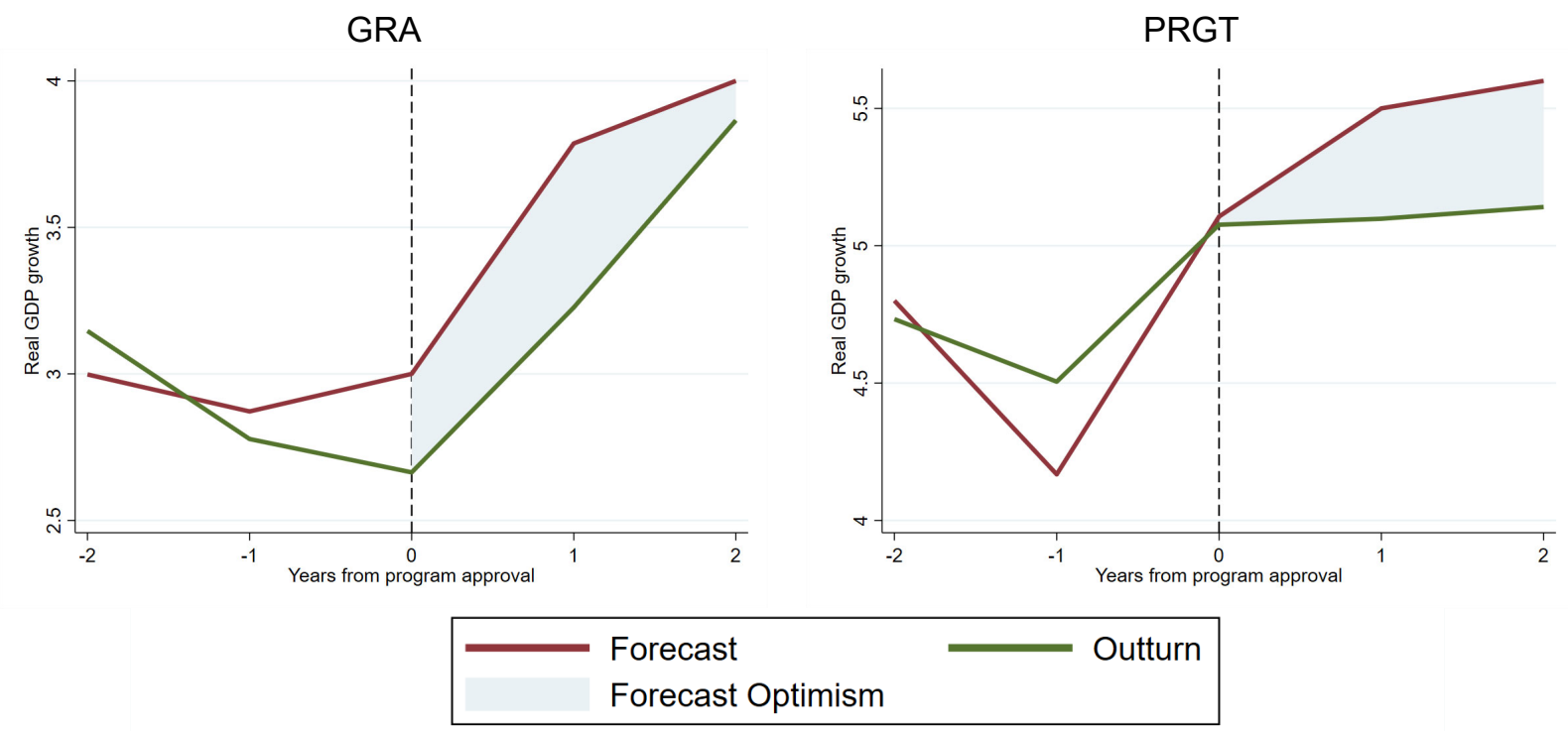

Sources: WEO, MONA, and authors' calculations.

Notes: Figure shows median across 129 IMF-supported programs supported by GRA resources and 177 programs supported by PRGT resources that were approved between 2000 and 2019 . Forecasts are those made at program request and accessed from the IMF's MONA database, while outturns are from the October 2021 vintage of the World Economic Outlook.

following the global financial crisis. They conclude that this forecast inefficiency is suggestive that IMF forecasters had underestimated the size of the fiscal multiplier in this sample. A similar approach has more recently been undertaken by Ismail, Perrelli, and Yang (2020), who additionally document a non-linearity in the relationship between forecast optimism and the size of the planned fiscal adjustment. Our main contribution is to apply this approach to study the role of financial variables, specifically the evolution of credit to the private sector, which will allow us to infer whether macrofinancial analysis is being properly incorporated into the IMF's program forecasts.

Why might one suspect that inefficient use of financial variables could be driving forecast optimism? Figure 2 plots the evolution of the credit-to-GDP gap surrounding the approval of IMF-supported programs. ${ }^{4}$ We have separated each sample based on the ex-post error of the program's growth forecast, splitting the sample at the top quartile of the empirical distribution. For those GRA programs that ended up being most optimistic, we notice a large swing in the credit cycle surrounding program approval. For the median program in this sub-sample, the credit-to-GDP gap increases by over 6 percentage points in the three years prior to program approval, only to revert sharply in the following years. This pattern is not observed in programs that featured little or no forecast optimism; nor is it observed in the sample of PRGT programs, whose low-income beneficiaries tend to have lower levels of financial development.

Our motivation for testing the efficient use of financial variables originates in the large literature on their predictive power for forecasting output growth, prominently explored by Stock and Watson (2003) for the

${ }^{4}$ Details on data sources and variable construction will be provided in the following sections. The credit-to-GDP gap corresponds to the deviation of the ratio of credit to the private sector to GDP from its trend. 
Figure 2. Evolution of the Credit-to-GDP Gap Surrounding the Approval of IMF-Supported Programs

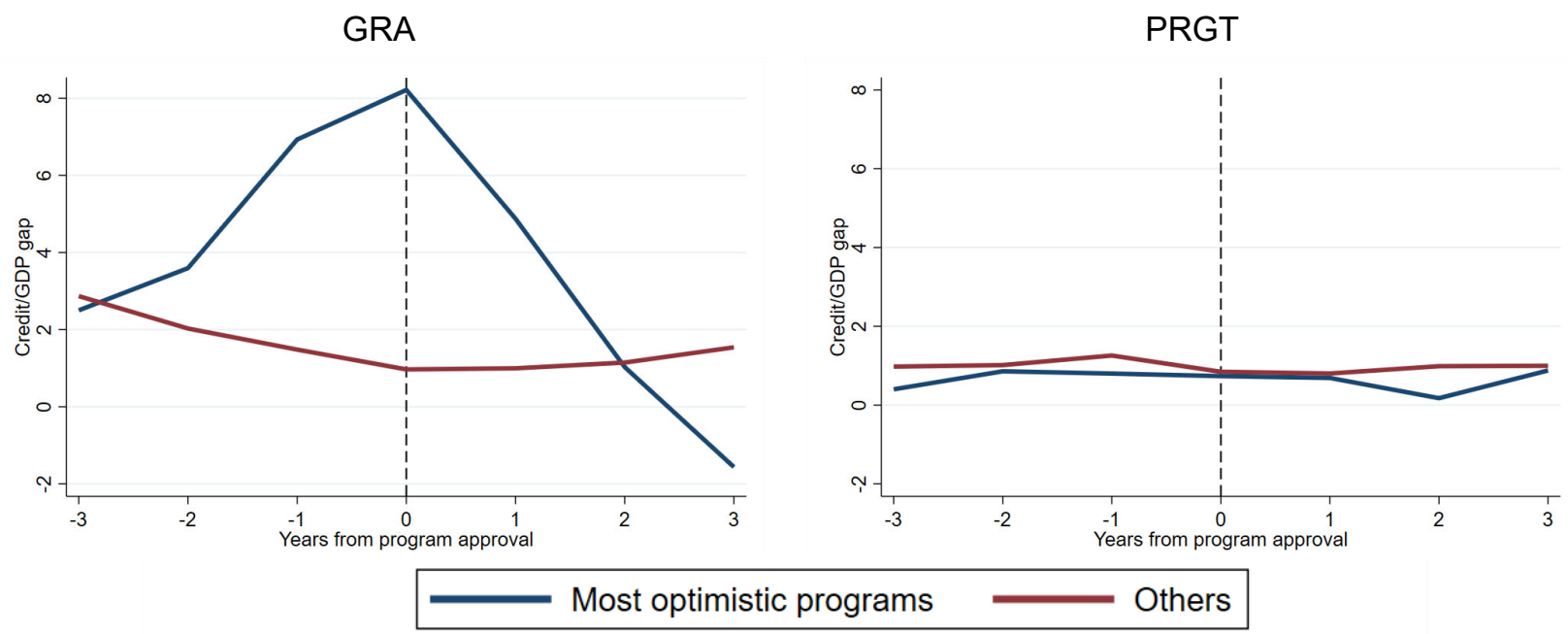

Sources: WEO, MONA, BIS, IFS, BOP, and authors' calculations.

Notes: Figure shows medians across programs for which the credit-to-GDP gap could be estimated using available data. "Most optimistic programs" in each panel are those in the top quartile of growth forecast errors $\hat{g}_{i}$ defined in equation 1.

case of the United States. Adrian, Boyarchenko, and Giannone (2019) show that financial indicators are good predictors of the conditional mean and variance of future output growth in the United States, arguing that this feature is driven by amplification mechanisms between the financial sector and real economy. Chen and Rancière (2019) present simple models incorporating financial variables including credit growth that provide good out-of-sample accuracy when forecasting output in a sample of 62 countries. Closely related to our work, they show that the models outperform the IMF's World Economic Outlook (WEO) in an out-of-sample horserace of forecast accuracy for 85 percent of the countries they study. Kirti (2018) finds that strong credit growth is a good predictor of future growth and unemployment three years hence. He also documents that this relationship is compounded by the strength of lending standards: when strong credit growth is accompanied by a deterioration of lending standards, this is followed by even weaker growth and higher unemployment.

But if the literature has documented that financial conditions are good predictors of future output growth, is this fact being fully incorporated into macroeconomic forecasts? Kirti (2018) tests this hypothesis on a sample of WEO forecasts for 38 countries, and finds that the documented relationship between financial and real variables is not anticipated by forecasters, with past credit developments correlating strongly with ex post forecast errors.

We believe our paper is the first to examine whether growth forecasts made in the context of IMF-supported programs efficiently use the information contained in observable financial variables. These programs offer an interesting context that may differ from forecasts produced in the IMF's World Economic Outlook surveillance forecasts and those produced by professional forecasters in the private sector. A first way programs differ is that they are usually designed in a context where a negative shock has already materialized, creating a gap in the balance of payments and prompting the country's authorities to seek financial assistance from the international community. There is an extensive literature documenting the failure of professional economists-including those at the IMF-to anticipate recessions (Loungani 2001; 
An, Jalles, and Loungani 2018). This stylized fact generates an optimism bias that is particularly pronounced in samples with many large negative shocks. Programs thus offer an interesting context because the accuracy of their forecasts rely less on ability to anticipate a negative shock, but rather from anticipating the depth of downturns and the strength of recoveries following a realized shock. A second way program growth forecasts differ is that they must be jointly agreed between the Fund and the member country, and this process may involve political incentives to bias a forecast towards optimism or pessimism, as discussed by Musso and Phillips (2002). One aspect of this is that IMF policy prevents the institution from lending if public debt is not assessed to be on a sustainable path, and this assessment is heavily influenced by growth forecasts.

Our paper also relates to the literature on sources of bias and inefficiency in macroeconomic forecasts made by the IMF and by other forecasters (Timmermann 2007; Eicher and others 2019). Blanchard and Leigh (2013) provide a prominent example of inefficient program forecasts: the under-estimation of the impact of a planned fiscal consolidation on growth during the Euro area crisis of 2010-11. Our paper confirms that misestimation of fiscal multipliers may have been a factor in explaining optimistic program forecasts, though the result is not statistically significant in our sample.

Our main result is that financial variables observable during program design-particularly the recent evolution of the credit-to-GDP gap_-are reliable and strong predictors of growth forecast errors. A program preceded by a one standard deviation increase in the credit-to-GDP gap-approximately 8.1 percentage points in our sample-is associated with an annualized forecast error that is approximately 0.60 percentage points more optimistic, such that the level of output is over-estimated by about 1.2 percentage points at a two-year horizon. This result is about twice as strong among those programs whose growth forecasts turned out to be optimistic.

While we do not attempt to provide a comprehensive decomposition of the drivers of forecast errors, we explore plausible explanations for the inefficient use of information in financial variables. A plausible mechanism underlying this result is that a program's policy adjustments are endogenous, with programs following a credit boom calibrated to tighten financial conditions. This could give rise to inefficient forecast optimism if the impact of these policies on growth was underestimated. Relatedly, more restrictive policies may be less likely to be implemented due to political resistance, making programs approved after a credit boom more likely to go "off track" with agreed policies not being implemented as planned. We present some evidence that these explanations are unlikely to explain our result. Rather, we deduce that forecasters do not correctly model the relationship between the past and future evolution of observable variables-possibly underestimating the tendency of credit to revert to its trend-and the interactions of the credit cycle and real economy.

We show that our result also applies outside the context of IMF-supported programs, including in a large panel of WEO forecasts made in the institution's surveillance role, and in forecasts made by professional forecasters. However, the size of the effect appears to be smaller than what is estimated in our event study of IMF-supported programs. We take this as an indication that improved macrofinancial analysis could alleviate the optimism of growth forecasts across the profession. From an institutional perspective, our results emphasize the importance of the IMF's efforts to continue deepening macrofinancial analysis as highlighted in the recent Comprehensive Surveillance Review (IMF 2021a; IMF 2021b), by underscoring the importance of such analysis also in the context of program design.

The paper is organized as follows. In section 2, we document stylized facts about growth forecast errors in IMF-supported programs, and present our first empirical approach based on an event study. In section 3, we present a second empirical approach that considers a broad panel of IMF forecasts that spans both 
program and surveillance contexts, as well as forecasts made by professional forecasters. Section 4 concludes.

\section{EVEnT StUdy OF IMF-SUPPORTEd PROgRAMS}

Our first empirical approach studies forecasts made upon approval of IMF-supported programs initiated between 2000 and 2019, as reported in the Monitoring of Fund Arrangements (MONA) database. ${ }^{5}$ During this period there were 306 IMF-supported programs approved, of which 129 were supported by GRA resources and 177 by concessional PRGT resources reserved for low-income member countries. ${ }^{6}$

Following Blanchard and Leigh (2013), we summarize growth performance using the annualized growth rate of real output over the two years following the approval of program $i$ in year $t$, which we denote $g_{c, i}$. That is, we consider the difference between the level of real output $y_{c}$ from periods $t-1$ to $t+1$ :

$$
g_{c, i}=\left(\sqrt{\left[y_{c, t+1} / y_{c, t-1}\right]}-1\right) \times 100
$$

The choice of a two-year horizon is meant to capture short-to-medium-term outcomes, which can be thought to be most directly affected by the approval of the IMF-supported program. ${ }^{7}$ We then define the forecast error $\hat{g}_{i}$ as the difference between the forecast made at the time of the program approval and the outturn:

$$
\hat{g}_{i}=E_{b} g_{c, i}-g_{c, i},
$$

where $E_{b}$ is the expectations operator conditional on the information set available at date $b$, when the program was approved by the IMF's Executive Board, and $g_{c, i}$ is the outturn for the variable as reported in the October 2021 vintage of the World Economic Outlook database. A positive value of $\hat{g}_{i}$ denotes an optimistic growth forecast (that is, growth turned out to be lower than anticipated), while a negative value denotes a pessimistic growth forecast (that is, growth was higher than anticipated).

Figure 3 plots $\hat{g}_{i}$ for all IMF-supported programs since 2000, with GRA programs marked by blue circles and PRGT programs marked in purple. The average of $\hat{g}_{i}$ in the full sample of programs over this period is 0.8 , with a median of 0.4 and standard deviation of 3.9 - this is the optimism bias that has been identified in the literature (Kim and others 2021). It is also worth noting that many programs contain growth forecasts that turned out to be remarkably accurate: one quarter have a value of $\hat{g}_{i}$ that is within 0.68 percentage points of zero. The within-year median value of $\hat{g}_{i}$ is shown in blue diamonds, with values that are generally close to zero except for years associated with major global crises (notably, 2008 and 2019). ${ }^{8}$ Indeed, GRA programs approved outside these two years have a median value of $\hat{g}_{i}$ of 0.07 over 2000-19. That is, in the absence of an unanticipated global crisis, about half of IMF-supported programs contained growth forecasts that turned out to be optimistic, while the other half were too pessimistic.

\footnotetext{
5 The database and related documentation are publicly available at imf.org/external/np/pdr/mona/index.aspx. We do not consider forecasts made at the time of program reviews in this exercise, but will do so in Section 3.

${ }^{6}$ The dataset does not include disbursements of emergency lending under the Rapid Credit Facility or Rapid Financing Instrument, which are not accompanied by program conditionality nor subject to periodic reviews.

7 Some studies have evaluated longer-horizon forecasts, including Beaudry and Willems (2021) and Ho and Mauro (2006). We conduct robustness checks of our main results at the three-year horizon.

8 The 32 IMF-supported programs approved in 2008 and in 2019 have a median value of $\hat{g}_{i}$ of nearly 3.1.
} 
Figure 3. Forecast Errors Following Approval of IMF-Supported Programs

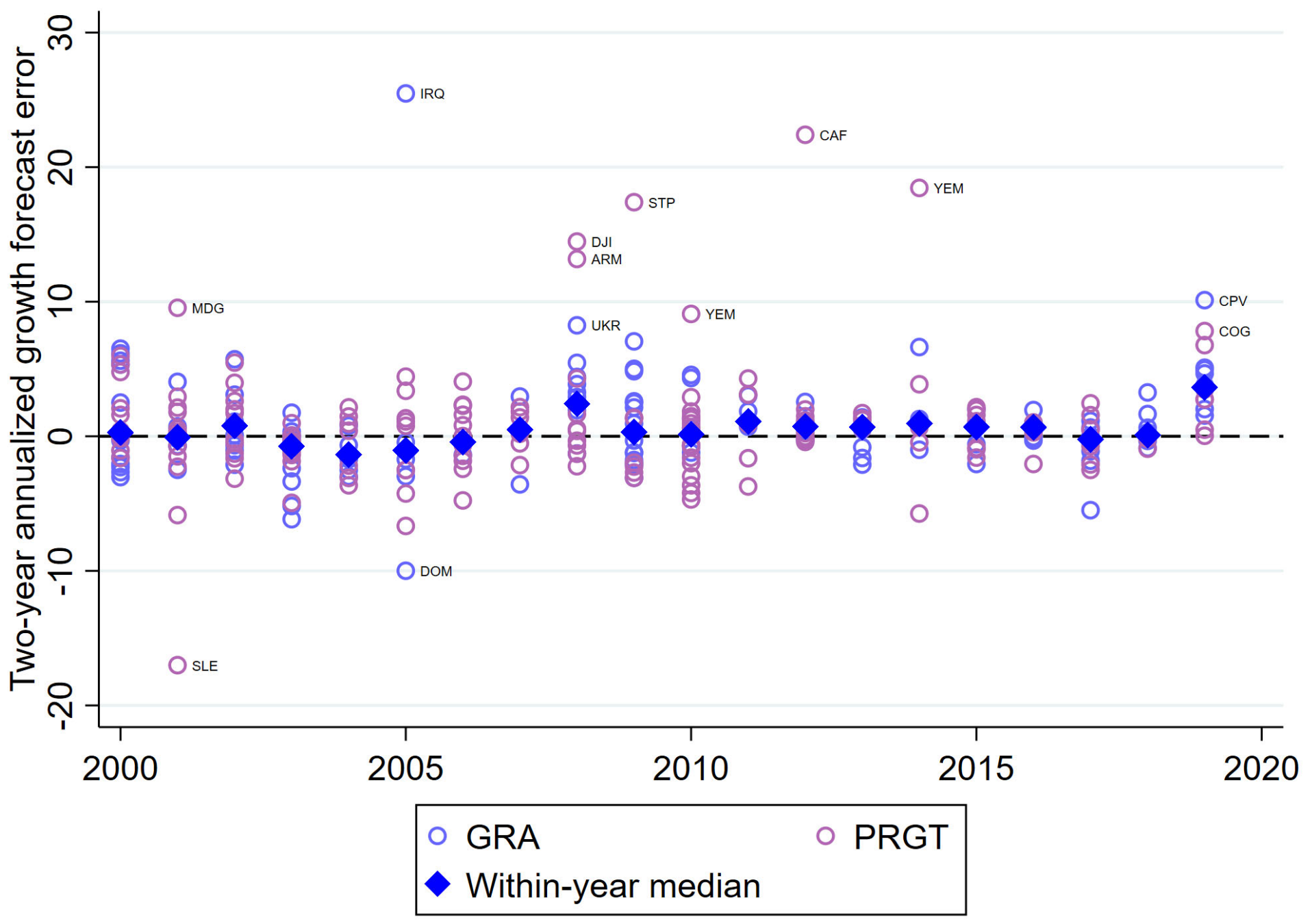

Sources: WEO, MONA, and authors' calculations.

Note: For each program we plot the annualized forecast error over the two years following program approval $\left(\hat{g}_{i}\right)$

Sources: Authors' calculations of forecast errors based on forecasts from the IMF's Monitoring of Fund Arrangements database and outturns from the October 2021 vintage of the World Economic Outlook. 
Programs in low-income economies supported by concessional PRGT resources exhibit larger variance of forecast errors, with a number displaying extremely large annualized forecast errors of upwards of 10 to 20 percentage points. This could stem from characteristics of the borrowing countries, such as their vulnerability to large shocks such as civil conflicts and natural disasters, as well as their less diversified production structures and lower data quality (Eicher and others 2019). There are 13 programs in this sample for which $\hat{g}_{i}$ is more than two standard deviations from zero, and these have been labeled with the country code. According to data from the Uppsala Conflict Data Program (UCDP), eight of these program requests took place within three years of an episode of organized violent conflict. ${ }^{10}$

Our baseline specification is an event study that regresses program i's growth forecast error on a set of explanatory variables:

$$
\hat{g}_{i}=\alpha+\boldsymbol{\delta} \boldsymbol{X}_{t-1, i}+\beta C_{i}+\gamma \dot{y}_{t-1, i}+\gamma_{2019}+\varepsilon_{i},
$$

where $\hat{g}_{i}$ is defined in equation 1 , and time $t$ is the year of program approval. The vector $\boldsymbol{X}_{t-1, i}$ contains macrofinancial variables that belong to the information set observable to the forecaster at the time of program approval, which is the basis for our forecast efficiency test. The null hypothesis of an efficient forecast is that the coefficients $\delta$ on regressors in the information set are equal to zero, and that forecasts are unbiased with intercept $\alpha$ equal to zero. If the null is rejected, this would suggest that information contained in these variables has not been properly incorporated into program forecasts, and that this is a source of forecast error.

In this first empirical approach, $\boldsymbol{X}_{t-1, i}$ includes a single variable: the change in the credit-to-GDP gap over the two years preceding program approval (that is, from $t-3$ to $t-1$ ). The credit-to-GDP gap is computed as the deviation of the ratio of credit to the private sector to GDP from its trend. To ensure that the variable belongs to the information set, we construct it using two features. First, the GDP series used in the denominator of the credit-to-GDP ratio is taken from the WEO vintage immediately preceding program approval at date $b$. This avoids the introduction of non-trivial data revisions to the output series, which would not have been in the information set available to the forecaster. Second, the trend of the ratio is computed using a one-sided five-year moving average (rather than the commonly used two-sided HP filter), which does not incorporate information on subsequent data.

The decision to focus on aggregate credit rather than a battery of market-based financial indicators may lead to some information loss, but allows us to study a large sample of countries-twice as large as previous papers such as Kirti (2018) and Chen and Rancière (2019)-including low-income economies with less developed financial systems. ${ }^{11}$ Our full estimation sample consists of 218 programs (89 GRA and 129 PRGT) for which credit aggregate series are available for at least seven years prior to program approval, allowing us to compute our measure of the real-time credit-to-GDP gap.

\footnotetext{
10 The UCDP dataset is presented in Sundberg and Melander (2013) and updated in Högbladh (2021).

${ }^{11}$ Data on bank credit to the non-financial private sector was obtained from the Bank for International Settlements for 43 OECD and large emerging market countries. For an additional 144 countries, domestic bank credit was obtained from the IMF's International Financial Statistics. For 19 of these countries from Central and Eastern Europe-where credit from non-resident banks has been large-in addition to domestic bank credit, we add the loans and securities owed to non-residents from the IMF's Balance of Payments database, where timely and sufficiently long data series are available.
} 
Table 1. Results from Event Study Regressions

\begin{tabular}{|c|c|c|c|c|c|c|c|}
\hline & (1) & (2) & (3) & (4) & (5) & (6) & (7) \\
\hline $\begin{array}{l}\text { Credit-to-GDP gap } \\
\text { (change from } t-3 \text { to } t-1 \text { ) }\end{array}$ & $\begin{array}{l}0.07^{* * *} \\
(0.02)\end{array}$ & $\begin{array}{l}0.14^{* *} \\
(0.06)\end{array}$ & $\begin{array}{l}0.10^{* *} \\
(0.05)\end{array}$ & $\begin{array}{l}0.07^{* * *} \\
(0.02)\end{array}$ & $\begin{array}{l}0.08 \\
(0.10)\end{array}$ & $\begin{array}{l}0.06^{* * *} \\
(0.02)\end{array}$ & $\begin{array}{l}0.10^{* *} \\
(0.05)\end{array}$ \\
\hline Dummy: Civil conflict & $\begin{array}{l}1.67^{* *} \\
(0.65)\end{array}$ & $\begin{array}{l}1.79^{* *} \\
(0.68)\end{array}$ & $\begin{array}{c}2.04^{* * *} \\
(0.66)\end{array}$ & $\begin{array}{c}0.79 \\
(0.64)\end{array}$ & $\begin{array}{l}2.34^{* *} \\
(0.93)\end{array}$ & $\begin{array}{l}1.49^{* *} \\
(0.67)\end{array}$ & $\begin{array}{l}2.38^{* *} \\
(1.06)\end{array}$ \\
\hline $\begin{array}{l}\text { Output growth } \\
(t-1)\end{array}$ & $\begin{array}{l}0.12^{* *} \\
(0.05)\end{array}$ & $\begin{array}{c}0.13 \\
(0.08)\end{array}$ & $\begin{array}{l}0.10^{*} \\
(0.06)\end{array}$ & $\begin{array}{l}0.13^{* *} \\
(0.06)\end{array}$ & $\begin{array}{l}0.17^{* *} \\
(0.08)\end{array}$ & $\begin{array}{l}0.10^{* *} \\
(0.04)\end{array}$ & $\begin{array}{c}0.11 \\
(0.07)\end{array}$ \\
\hline Dummy: 2008 & & & & & & $\begin{array}{l}2.08^{*} \\
(1.19)\end{array}$ & \\
\hline Dummy: 2011 & & & & & & $\begin{array}{l}1.54^{*} \\
(0.79)\end{array}$ & \\
\hline Dummy: 2019 & $\begin{array}{l}3.87^{* * *} \\
(0.91)\end{array}$ & $\begin{array}{l}2.29^{* *} \\
(0.96)\end{array}$ & $\begin{array}{l}3.19^{* * *} \\
(0.63)\end{array}$ & $\begin{array}{l}3.88^{* * *} \\
(1.18)\end{array}$ & $\begin{array}{c}4.07^{* * *} \\
(1.41)\end{array}$ & $\begin{array}{l}4.08^{* * *} \\
(0.92)\end{array}$ & $\begin{array}{c}3.20^{* * *} \\
(1.13)\end{array}$ \\
\hline Constant & $\begin{array}{l}-0.45 \\
(0.27)\end{array}$ & $\begin{array}{l}1.17^{* * *} \\
(0.35)\end{array}$ & $\begin{array}{l}-0.47 \\
(0.29)\end{array}$ & $\begin{array}{l}0.15 \\
(0.30)\end{array}$ & $\begin{array}{l}-1.22^{* *} \\
(0.50)\end{array}$ & $\begin{array}{l}-0.52^{*} \\
(0.27)\end{array}$ & $\begin{array}{c}0.02 \\
(0.32)\end{array}$ \\
\hline Sample & Full & $\hat{g}_{i}>0$ & $\begin{array}{c}\text { Credit } \\
\text { gap }>0\end{array}$ & GRA & PRGT & Full & $\begin{array}{l}\text { Post- } \\
\text { GFC }\end{array}$ \\
\hline Observations & 218 & 128 & 160 & 89 & 129 & 218 & 105 \\
\hline Time period & $2000-19$ & $2000-19$ & $2000-19$ & $2000-19$ & $2000-19$ & $2000-19$ & $2010-19$ \\
\hline$R^{2}$ & 0.13 & 0.15 & 0.17 & 0.22 & 0.13 & 0.16 & 0.21 \\
\hline Mean of dep. variable $\left(\hat{g}_{i}\right)$ & 0.70 & 2.57 & 0.68 & 0.82 & 0.63 & 0.70 & 1.32 \\
\hline
\end{tabular}

Notes: White heteroskedasticity-robust standard errors clustered by country are shown in parentheses. The use of ${ }^{* \star *}$ denotes a coefficient significantly different from zero at the 0.01 confidence level; ${ }^{* *} 0.05 ;{ }^{*} 0.10$.

The baseline specification includes dummy variables to capture events that may be correlated with financial and output developments, but which are not directly caused by them and which we do not consider as being feasibly predicted or modelled by the forecaster. The dummy variable $\gamma_{2019}$ denotes that the program was approved during the year preceding the Covid-19 pandemic, which led to very large growth forecast errors shown in Figure 3. The dummy variable $C_{i}$ indicates that an episode of violent conflict occurred within three years of the program's approval. ${ }^{12}$ We also include the lagged growth rate of real output, to control for the economic cycle that prevailed prior to program approval. This is potentially important because it has been documented that growth forecasts may be revised inefficiently slowly during downturns (An, Jalles, and Loungani 2018).

Equation 1 is estimated by ordinary least squares, with estimates reported in Table 1 . Standard errors are estimated using a sandwich estimator that allows for cross-correlation of the error terms within country groups. Our rationale for using this approach is that IMF forecasts are derived from countryspecific forecasting models that are slow to evolve. This introduces a source of country-level variation in the data across time and forecast vintages.

The baseline specification reported in column 1 indicates that the change in the credit-to-GDP gap over the two years prior to the program is correlated with more optimistic growth forecasts in the full sample

\footnotetext{
12 We define country-years in which the number of organized violent events per 100,000 population is above the median score in the UCDP's Georeferenced Event Dataset (Sundberg and Melander 2013; Högbladh 2021).
} 
of 218 programs. ${ }^{13}$ For every percentage point that the credit-to-GDP gap increases in the two years prior to program approval, forecasts for annualized growth over the next two years display increased optimism of 0.075 percentage points. This elasticity is highly economically significant. A program preceded by a one standard deviation increase in the credit-to-GDP gap-approximately 8.1 percentage points in our sample-is associated with an annualized forecast error that is approximately 0.60 percentage points more optimistic, such that the level of output is over-estimated by about 1.2 percentage points at a two-year horizon.

Programs undertaken surrounding an episode of violent conflict and those approved in 2019 (prior to the global Covid-19 pandemic), display highly significant over-optimism on average. ${ }^{14}$ The conditional mean-estimated by the constant-is found to be insignificantly different from zero, indicating that there is no residual bias after controlling for these variables.

In column 2, we estimate the same specification on a sample that includes only those programs that ended up with optimistic growth forecasts, with $\hat{g}_{i}>0$. In this sample, the size of the coefficient on the credit-to-GDP gap is nearly twice as large as in the baseline. That is, the strength of the information inefficiency of growth forecasts with respect to financial variables is more pronounced among programs that end up being optimistic. Among these programs, a one standard deviation increase in the creditto-GDP gap is associated with an over-estimation of the level of output by about 2.3 percentage points at a two-year horizon. Among the 90 programs that had pessimistic growth forecasts $\left(\hat{g}_{i} \leq 0\right.$; not reported in Table 2), the credit-to-GDP gap is no longer statistically significant and the coefficient becomes slightly negative, indicating that the inefficiency we document applies only to those programs whose growth forecasts end up being optimistic.

In the third column, we restrict the sample to programs that have a positive credit-to-GDP gap in the year prior to their approval, which allows us to test the symmetry of our result over the credit cycle. We find that the coefficient here is also somewhat larger than in the full sample. Among the 58 programs that were preceded by a negative credit-to-GDP gap (results not reported in Table 2), the coefficient of the credit-to-GDP gap is positive but is no longer statistically significant, indicating that the inefficiency we document is strongest among those programs that are preceded by a positive credit-to-GDP gap.

The next two columns estimate the same equation, but separate the full sample according to whether programs are supported by GRA or PRGT resources. ${ }^{15}$ The results show that while the coefficient on the credit-to-GDP gap is of a similar magnitude across the two groups -0.07 for GRA programs versus 0.08 for PRGT-supported programs-its statistical significance is only confirmed in the first group. This may reflect the greater relative importance of the financial system in advanced and emerging economies-which rely on GRA resources-in comparison to the low-income economies that can opt for more concessional PRGT facilities, or simply the greater volatility in the data for the latter sample.

\footnotetext{
${ }^{13}$ As a robustness check, we also generated Table 1 using a horizon of three years for the forecast error as the dependent variable - as in Beaudry and Willems (2021). The results reported here remain unchanged and are significant at conventional confidence levels, though the economic significance of the relationship appears to be somewhat weaker at the longer horizon.

${ }^{14}$ As an additional robustness check, we estimate Table 1 on a sample that excludes programs approved in 2019, whose outturns were affected by the Covid-19 pandemic. Our results remain unchanged.

${ }^{15}$ As a robustness check, we exclude from the estimations in Table 1 those programs that correspond to precautionary credit lines (the Flexible Credit Line and the Precautionary Liquidity Line) and to programs that do not involve financial (the Policy Coordination Instrument and the Policy Support Instrument). Results remain unchanged.
} 
Table 2. Results Including Effect of Programmed Policy Adjustments

\begin{tabular}{|c|c|c|c|}
\hline & (1) & (2) & (3) \\
\hline $\begin{array}{l}\text { Credit-to-GDP gap } \\
\text { (change from } t-3 \text { to } t-1 \text { ) }\end{array}$ & $\begin{array}{l}0.15^{* *} \\
(0.07)\end{array}$ & $\begin{array}{l}0.16^{* *} \\
(0.08)\end{array}$ & $\begin{array}{l}0.08^{* *} \\
(0.04)\end{array}$ \\
\hline Dummy: Civil conflict & $\begin{array}{l}2.05^{* *} \\
(0.80)\end{array}$ & $\begin{array}{l}2.02^{* *} \\
(0.81)\end{array}$ & $\begin{array}{l}1.80^{*} \\
(0.98)\end{array}$ \\
\hline $\begin{array}{l}\text { Output growth } \\
(t-1)\end{array}$ & $\begin{array}{l}0.21^{* * *} \\
(0.08)\end{array}$ & $\begin{array}{c}0.21^{* * *} \\
(0.08)\end{array}$ & $\begin{array}{c}0.13 \\
(0.09)\end{array}$ \\
\hline Dummy: 2019 & $\begin{array}{c}3.38^{* * *} \\
(1.11)\end{array}$ & $\begin{array}{c}3.49^{* * *} \\
(0.96)\end{array}$ & $\begin{array}{c}2.52^{* * *} \\
(0.69)\end{array}$ \\
\hline $\begin{array}{l}\text { Exp. real growth base money } \\
(t-1 \text { to } t+1)\end{array}$ & $\begin{array}{l}-0.02 \\
(0.04)\end{array}$ & & \\
\hline $\begin{array}{l}\text { Exp. change in money multiplier } \\
(t-1 \text { to } t+1)\end{array}$ & & $\begin{array}{c}0.18 \\
(0.88)\end{array}$ & \\
\hline $\begin{array}{l}\text { Exp. fiscal adjustment } \\
(t-1 \text { to } t+1)\end{array}$ & & & $\begin{array}{l}0.17 \\
(0.14)\end{array}$ \\
\hline Constant & $\begin{array}{l}-0.63 \\
(0.43)\end{array}$ & $\begin{array}{l}-0.70^{*} \\
(0.42)\end{array}$ & $\begin{array}{l}-0.78^{*} \\
(0.43)\end{array}$ \\
\hline $\begin{array}{l}\text { Observations } \\
\mathrm{R}^{2} \\
\text { Time period } \\
\text { Sample }\end{array}$ & $\begin{array}{c}91 \\
0.27 \\
2002-19 \\
\text { Full } \\
\end{array}$ & $\begin{array}{c}92 \\
0.27 \\
2002-19 \\
\text { Full } \\
\end{array}$ & $\begin{array}{c}136 \\
0.10 \\
2000-19 \\
\text { Full } \\
\end{array}$ \\
\hline
\end{tabular}

Notes: White heteroskedasticity-robust standard errors clustered by country are shown in parentheses. The use of ${ }^{* * *}$ denotes a coefficient significantly different from zero at the 0.01 confidence level; ${ }^{* *} 0.05$; * 0.10 .

Other factors appear to be important in the latter group. Notably, PRGT-supported programs that coincide with violent conflict are associated with significantly greater optimism, with the annualized growth forecast error 2.3 percentage points larger in these cases. The conflict variable does not appear to be significantly related to growth forecast errors in the sample of GRA-supported programs.

In column 6, we introduce additional dummy variables indicating programs approved prior to two major global financial shocks: 2008 for the global financial crisis, and 2011 for the euro area crisis. While our baseline finding may largely reflect the well-studied correlation between pre-crisis financial conditions and the impact of global shocks on growth, we wish to ensure that the result is not exclusively driven by these events. Both these dummies are found to capture significant common forecast optimism-as can also be perceived visually in Figure 3-but the null hypothesis of an efficient forecast in which $\delta=0$ can still be rejected.

Finally, column 7 estimates the model on the subset of programs that were approved after the Global Financial Crisis, between 2010 and 2019. Following the GFC, it became widely recognized that credit expansions are often followed by deep and persistent recessions (Claessens, Kose, and Terrones 2009). However, we find that forecast errors made in the post-GFC period remain highly correlated with the past evolution of the credit-to-GDP gap, with the size of the coefficient increasing to 0.10 . This suggests that growth forecasters have not become more efficient at incorporating the information in financial variables. Notably, our parsimonious specification explains a higher share of the variance in 
$\hat{g}_{i}$ over the more recent period, with the $\mathrm{R}^{2}$ increasing from 0.13 in the full sample to 0.21 in the shorter sample.

\section{Exploring Potential Channels of Macrofinancial Inefficiency}

What mechanism explains the inefficient use of financial information in growth forecasts? A plausible hypothesis is that pre-program credit expansions are met with particularly restrictive program policy conditionality. These policy adjustments may in turn lead to forecast optimism if they are more politically challenging to implement, or if their impact on growth is underestimated. To test this hypothesis, we augment the baseline equation to include measures of expected monetary, financial and fiscal policy adjustment, reporting the results in Table 2 .

In column 1, we proxy for programmed monetary adjustment using the expected rate of growth of the monetary base over the next two years, deflated by the expected growth of the consumer price index. Most IMF-supported programs include monetary conditionality that sets an upper bound on the growth rate of the monetary base, with this becoming the operational target by which the stance of monetary policy is implemented. We find that this variable is not significantly correlated with growth forecast errors, and that the economic and statistical significance of the pre-program credit-to-GDP gap is unaffected. ${ }^{16}$ This allows us to conclude that the inefficiency we have identified is not generated by the endogenous calibration of program conditionality in response to pre-program credit conditions.

Monetary policy may provide an incomplete measure of the programmed policy adjustment's impact on financial conditions. For instance, a build-up in credit may be met by a tightening of macroprudential policies such as reserve requirements, which can moderate credit intermediation for a given stance of monetary policy. In column 2, we proxy for the programmed adjustment of financial conditions using the expected change in the money multiplier-that is, the ratio of broad money to the monetary basefrom period $t-1$ to $t+1$. Again, we find that this variable is not significantly correlated with growth forecast errors. In a final exercise reported in column 3, we introduce a measure of programmed fiscal adjustment, as in Blanchard and Leigh (2013) and Ismail, Perrelli, and Yang (2020). We construct the expected change in the overall fiscal balance as a share of GDP from $t-1$ to $t+1$, capturing the expected fiscal effort over the forecast horizon. ${ }^{17}$ We confirm that planned fiscal adjustments appears positively correlated with forecast optimism-suggesting that fiscal multipliers may be somewhat underestimated-but the result is not statistically significant in this sample..$^{18}$ Even after controlling for programmed adjustment of monetary, financial, and fiscal policies, forecast optimism remains significantly correlated with the pre-program evolution of the credit-to-GDP gap.

These exercises have focused on planned policy adjustments, but an alternative mechanism for our baseline result could be that a pre-program credit boom makes it harder to implement agreed policies, making it more likely that the program goes "off track". Since forecasts at program approval must

\footnotetext{
${ }^{16}$ Note that the MONA database does not include comprehensive reporting of the policy variables used in Table 2. The sample size is thus smaller in each of these estimations than it is in the baseline, which is responsible for some of the variation in coefficients.

17 We truncate the variable such that the overall adjustment is no larger than 10 percentage points of GDP or no smaller than -10 percentage points of GDP, which excludes two programs from the sample. Note that Blanchard and Leigh (2013) use a measure of the structural fiscal balance, but this information is not available for a large sample in the MONA database.

${ }_{18}$ Blanchard and Leigh (2013) define their forecast error variable with the opposite sign than we do in equation 1 , such that our estimated coefficients must be multiplied by -1 for comparison.
} 
assume that policies will be implemented as planned, this could lead to a source of optimism in growth forecasts. To test this hypothesis, we compute the forecast errors for the two proxies of monetary and financial policy adjustment described above, and regress these on our measure of pre-program credit developments. We find that neither variable is significantly correlated. Likewise, policy adjustment forecast errors are not significantly correlated with the degree of planned policy adjustment. Taken together, we conclude that the inefficiency we have identified is unlikely to be explained by the degree of program implementation.

An alternative explanation for the inefficient use of financial variables in growth forecasts is the inherent difficulty in distinguishing in real time between an ongoing credit expansion that is structural-reflecting a process of financial development-from a cyclical boom. ${ }^{19}$ Our interpretation of the relationship we identify in this section is that forecasters are biased towards the structural interpretation of credit expansions. They thus fail to forecast either the mean reversion of private credit, or the impact of this cyclical credit reversion on growth.

\section{Panel Analysis of Growth Forecasts}

In our second empirical approach, we build a panel of semi-annual IMF forecasts from successive vintages of the World Economic Outlook for 130 countries, as well as the 497 forecasts made in the context of program requests and reviews reported to MONA over the sample period. This larger set of growth forecasts allows us to include a set of more granular control variables, and to explore some of the possible channels through which financial conditions are associated with forecast errors. We also wish to understand whether the forecast inefficiency found in the previous section is specific to the context of an IMF-supported program approval, or whether it prevails in other contexts as well.

The unit of observation in our panel is defined by a country $c$, forecast vintage $v$, and year $t$. For each vintage-country, our specification admits a single observation of the dependent variable $\hat{g}_{c, t+1}^{v}$, which as defined in equation 1 measures the forecast error for the annualized growth rate in years $t$ and $t+1$. The empirical distributions of $\hat{g}_{c, t+1}^{v}$ in our panel are plotted by the histograms in Figure 4, where we distinguish forecasts made in the context of an IMF-supported program from those made in other contexts. The sample mean and median of $\hat{g}_{c, t+1}^{v}$ is 0.00 and -0.11 in the program sample, and 0.32 and 0.03 in the no-program sample. ${ }^{20}$

We regress $\hat{g}_{c, t+1}^{v}$ on a vector of observable financial variables $\boldsymbol{X}_{c, t-1}^{v}$ and vintage-specific control variables $\boldsymbol{Y}_{c, t+1}^{v}$ :

$$
\hat{g}_{c, t+1}^{v}=\alpha+\delta \boldsymbol{X}_{c, t-1}^{v}+\boldsymbol{\rho} \boldsymbol{Y}_{c, t+1}^{v}+\varepsilon_{c, t+1}^{v}
$$

\footnotetext{
19 One aspect of this challenge common in the experience of emerging and developing economies-narrated by Díaz-Alejandro (1985) for the case of several Latin American countries-is that the process of financial development is accompanied and facilitated by rapid deregulation, which leads to financial and macroeconomic instability.

${ }^{20}$ Recall that the median forecast error among program requests reported in Section 2 was 0.4 percentage points. This suggests that forecast optimism is less widespread in program reviews than in program requests. This may suggest that there is some degree of learning by doing in forecasting over the course of a Fund-supported program, with optimism being more pronounced at the program approval stage than during subsequent program reviews.
} 
Figure 4. Distributions of IMF Growth Forecast Errors; 2003-19

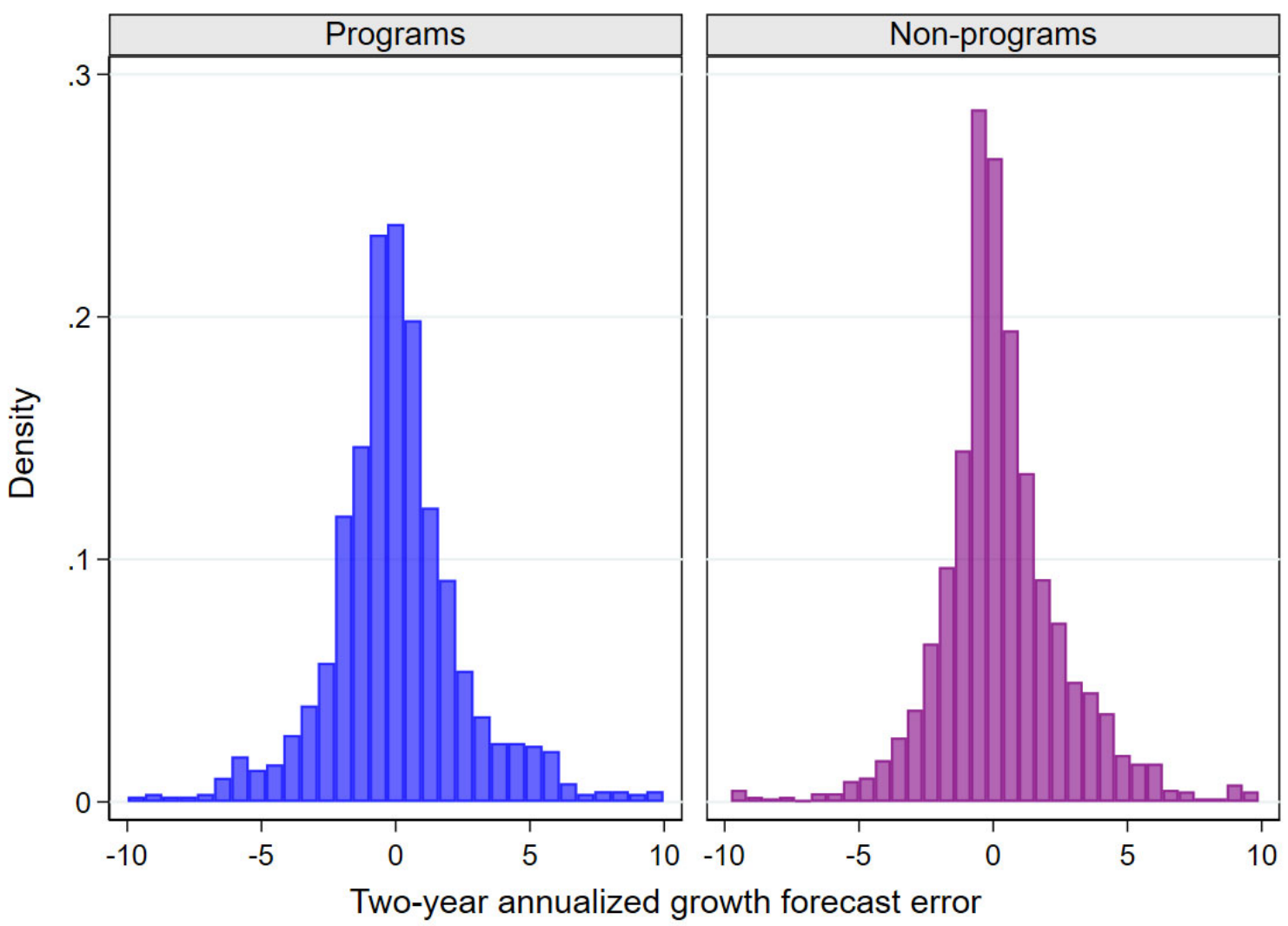

Sources: WEO, MONA, and authors' calculations.

Note: Distribution of the annualized forecast errors over a two-year horizon $\left(\hat{g}_{c, t}^{v}\right)$. Forecasts from the IMF's Monitoring of Fund Arrangements and World Economic Outlook databases, and outturns from the October 2021 vintage of the World Economic Outlook. Values of $\hat{g}_{c, t}^{v}$ above 10 percentage points or below -10 percentage points have been omitted from the histograms for readability.

In the baseline specification, the vector $\boldsymbol{X}_{c, t-1}^{v}$ contains the recent evolution of the credit-to-GDP gapdefined the same way as in section 2-as well as the lagged share of loans by banks to non-financial corporates that are denominated in foreign currency, as reported in the IMF's Monetary and Financial Statistics database. The latter is a state variable that captures a financial vulnerability that may amplify the impact of real and financial shocks on output.

The coverage of the WEO and MONA variables in this more recent period includes a richer set of vintage-specific forecasts that we can include in the vector $\boldsymbol{Y}_{c, t+1}^{v}$. A first variable is the ex post forecast error for the growth rate of country c's trading partners. These forecasts are taken from the IMF's internal Global Economic Environment (GEE) database, which forecasters are instructed to use as an input in their preparation of WEO forecasts for country $c .{ }^{21}$ This country-specific variable captures global

${ }^{21}$ There is a GEE vintage that corresponds to each published WEO vintage since 2003, which leads us to drop observations from 2000 to 2002. For program forecasts reported in MONA, we use the first preceding GEE vintage. 
shocks affecting the country's external demand conditions. ${ }^{22} \mathrm{~A}$ second variable is the change in the fiscal balance as a share of GDP from $t-1$ to $t+1$ that is expected in vintage $v$, which was also employed in estimations reported in Table 2 above. We again include in $\boldsymbol{Y}_{c, t+1}^{v}$ a dummy variable indicating that civil conflict took place in the forecast period, as well as the growth of real output prior to program approval. Finally, we include ex post revisions made to the level of real GDP in period $t-1$, which controls for forecast errors reflecting base effects from statistical revisions to national accounts.

The results from this exercise are presented in Table 3. Column 1 reports the baseline specification estimated on the panel of 1,425 country-vintage forecasts made in the context of an active IMFsupported program. We confirm the relationship identified in our event study of IMF-supported programs presented in the previous section: the recent evolution of the credit-to-GDP gap is significantly correlated with forecast errors, with a coefficient of 0.06 . However, the share of loans denominated in foreign currency is not found to be significant, with a coefficient that is very close to zero.

From our vector of controls, we find that the forecast errors of trading partners' growth are tightly correlated with forecast errors. This intuitive result reflects the fact that common global shocksincluding to commodity prices and financial conditions-are an important source of forecast errors in individual countries. When the GEE forecast for country c's partners turns out to be 1 percentage point too optimistic, this leads to an annualized growth forecast that is 0.5 percentage points more optimistic in the two following years.

The expected fiscal consolidation is not significantly correlated with forecast errors for growth, which is consistent with the results presented by Blanchard and Leigh (2013). As Blanchard and Leigh (2013) discuss, the macroeconomic and financial conditions surrounding the euro area crisis were particularly suited to generating larger-than-normal fiscal multipliers, and this does not seem to have been correctly anticipated by IMF growth forecasts at the time. However, they show that this result did not hold in other samples of WEO forecasts, including those that covered a longer period and a sample of emerging market economies. Our finding that expected fiscal consolidation is not significantly associated with more optimistic forecasts is suggestive that the IMF may be moving towards more realistic assumptions about fiscal multipliers. ${ }^{23}$

In column 2, we estimate the panel on the 2,374 country-vintage forecasts that were made outside in the absence of an active Fund-supported program, in the institution's surveillance role. The lagged change in the credit-to-GDP gap remains statistically significant, but the size of the coefficient is somewhat smaller at 0.02 . In column 3 , we estimate equation 3 on the full sample to 3,799 countryvintage forecasts-about 63 percent of which are generated outside the context of a IMF-supported program-covering 130 countries. The inefficiency result documented so far in the context of Fundsupported programs also holds in the Fund's surveillance forecasts-though its economic significance appears to be smaller-and the average effect is significant across all Fund forecasts.

\footnotetext{
22 Shocks to (common) global financial conditions are an important driver of domestic credit conditions in emerging markets (see, for instance, Carrière-Swallow and Céspedes 2013). We do not include time fixed effects in the baseline specifications-preferring to include the control for country-specific demand conditions-but Table 4 reports robustness checks in which we augment equation 3 with alternative fixed effects.

${ }^{23} \mathrm{~A}$ recent estimate of fiscal multipliers in emerging markets is provided by Carrière-Swallow, David, and Leigh (2021), who report that fiscal consolidations identified using a narrative approach are associated with a multiplier of 0.9 after two years in a sample of 14 countries in Latin America and the Caribbean. They show that this estimate is much larger than many previous estimates identified using timing assumptions or cyclical adjustments.
} 
Table 3. Results from Panel Forecast Efficiency Tests

\begin{tabular}{|c|c|c|c|c|c|c|c|}
\hline & $(1)$ & $(2)$ & (3) & (4) & (5) & (6) & (7) \\
\hline $\begin{array}{l}\text { Credit-to-GDP gap } \\
\text { (change from } t-3 \text { to } t-1 \text { ) }\end{array}$ & $\begin{array}{c}0.06^{* * *} \\
(0.02)\end{array}$ & $\begin{array}{l}0.02^{* *} \\
(0.01)\end{array}$ & $\begin{array}{l}0.03^{* * *} \\
(0.01)\end{array}$ & $\begin{array}{l}0.03^{* * *} \\
(0.01)\end{array}$ & $\begin{array}{l}0.03^{* * *} \\
(0.01)\end{array}$ & $\begin{array}{c}0.03^{* * *} \\
(0.01)\end{array}$ & $\begin{array}{l}0.02^{* * *} \\
(0.01)\end{array}$ \\
\hline $\begin{array}{l}\text { Share of loans denom. FX } \\
(t-1)\end{array}$ & $\begin{array}{l}-0.00 \\
(0.00)\end{array}$ & $\begin{array}{l}-0.00 \\
(0.00)\end{array}$ & $\begin{array}{l}-0.00 \\
(0.00)\end{array}$ & $\begin{array}{l}0.01^{* *} \\
(0.01)\end{array}$ & $\begin{array}{l}-0.01^{* *} \\
(0.00)\end{array}$ & $\begin{array}{l}-0.00 \\
(0.00)\end{array}$ & $\begin{array}{l}-0.00 \\
(0.00)\end{array}$ \\
\hline Dummy: Civil conflict & $\begin{array}{c}0.05 \\
(0.32)\end{array}$ & $\begin{array}{l}-0.30 \\
(0.33)\end{array}$ & $\begin{array}{l}-0.14 \\
(0.25)\end{array}$ & $\begin{array}{l}-0.09 \\
(0.43)\end{array}$ & $\begin{array}{l}-0.36 \\
(0.31)\end{array}$ & $\begin{array}{l}-0.17 \\
(0.25)\end{array}$ & $\begin{array}{l}-0.12 \\
(0.25)\end{array}$ \\
\hline $\begin{array}{l}\text { Exp. fiscal adjustment } \\
(t-1 \text { to } t+2)\end{array}$ & $\begin{array}{c}0.01 \\
(0.05)\end{array}$ & $\begin{array}{l}-0.02 \\
(0.04)\end{array}$ & $\begin{array}{l}-0.01 \\
(0.03)\end{array}$ & $\begin{array}{c}0.03 \\
(0.04)\end{array}$ & $\begin{array}{l}-0.04 \\
(0.05)\end{array}$ & $\begin{array}{c}0.02 \\
(0.02)\end{array}$ & $\begin{array}{l}-0.01 \\
(0.03)\end{array}$ \\
\hline $\begin{array}{l}\text { FE trade partners' growth } \\
(t+1)\end{array}$ & $\begin{array}{l}0.50^{* * *} \\
(0.06)\end{array}$ & $\begin{array}{l}0.50^{* * *} \\
(0.05)\end{array}$ & $\begin{array}{l}0.50^{* * *} \\
(0.04)\end{array}$ & $\begin{array}{l}0.23^{* * *} \\
(0.04)\end{array}$ & $\begin{array}{l}0.52^{* * *} \\
(0.05)\end{array}$ & $\begin{array}{c}0.50^{* * *} \\
(0.04)\end{array}$ & $\begin{array}{c}0.49^{* * *} \\
(0.04)\end{array}$ \\
\hline $\begin{array}{l}\text { Ex post revision to real GDP } \\
(t-1)\end{array}$ & $\begin{array}{l}-0.05 \\
(0.09)\end{array}$ & $\begin{array}{l}0.21^{* *} \\
(0.11)\end{array}$ & $\begin{array}{c}0.08 \\
(0.07)\end{array}$ & $\begin{array}{l}0.08 \\
(0.09)\end{array}$ & $\begin{array}{l}0.06 \\
(0.07)\end{array}$ & $\begin{array}{c}0.04 \\
(0.07)\end{array}$ & $\begin{array}{l}0.08 \\
(0.07)\end{array}$ \\
\hline $\begin{array}{l}\text { Real GDP growth } \\
(t-1)\end{array}$ & $\begin{array}{l}0.09^{* *} \\
(0.04)\end{array}$ & $\begin{array}{l}0.08^{* *} \\
(0.04)\end{array}$ & $\begin{array}{l}0.08^{* *} \\
(0.03)\end{array}$ & $\begin{array}{l}0.07 \\
(0.06)\end{array}$ & $\begin{array}{c}0.01 \\
(0.03)\end{array}$ & $\begin{array}{l}0.09^{* * *} \\
(0.03)\end{array}$ & $\begin{array}{l}0.08^{* *} \\
(0.03)\end{array}$ \\
\hline $\begin{array}{l}\text { REER Gap } \\
\text { (change from } t-3 \text { to } t-1 \text { ) } \\
\text { Interact: REER * Hi FX loans }\end{array}$ & & & & & & $\begin{array}{c}0.05^{\star * *} \\
(0.01) \\
-0.05^{\star *} \\
(0.02)\end{array}$ & \\
\hline $\begin{array}{l}\text { Dummy: Banking crisis } \\
\text { (t-1 or } t-2) \\
\text { Dummy: Banking crisis } \\
(t \text { or } t+1)\end{array}$ & & & & & & & $\begin{array}{c}0.06 \\
(0.51) \\
1.21^{* * *} \\
(0.41)\end{array}$ \\
\hline Constant & $\begin{array}{l}-0.24 \\
(0.31)\end{array}$ & $\begin{array}{c}0.02 \\
(0.16)\end{array}$ & $\begin{array}{l}-0.05 \\
(0.14)\end{array}$ & $\begin{array}{l}2.39^{* * *} \\
(0.28)\end{array}$ & $\begin{array}{c}0.19 \\
(0.15)\end{array}$ & $\begin{array}{l}-0.09 \\
(0.14)\end{array}$ & $\begin{array}{l}-0.09 \\
(0.15)\end{array}$ \\
\hline Sample & Program & $\begin{array}{c}\text { No } \\
\text { program }\end{array}$ & All & $\hat{g}_{c, t}^{v}>$ pct75 & $\begin{array}{l}\text { Consensus } \\
\text { Forecasts }\end{array}$ & All & All \\
\hline Observations & 1,425 & 2,374 & 3,799 & 948 & 2,056 & 3,727 & 3,799 \\
\hline $\mathrm{R}^{2}$ & 0.23 & 0.26 & 0.24 & 0.15 & 0.34 & 0.26 & 0.25 \\
\hline Time period & 2003-19 & $2003-19$ & 2003-19 & 2003-19 & 2003-19 & 2003-19 & 2003-19 \\
\hline Mean of dep. variable $\left(\hat{g}_{c, t}^{v}\right)$ & 0.00 & 0.32 & 0.20 & 3.51 & 0.07 & 0.22 & 0.20 \\
\hline
\end{tabular}

Notes: The dependent variable is $\hat{g}_{c, t+1}^{v}$, the forecast error for annualized growth of real output from $t-1$ to $t+1$. White heteroskedasticity-robust standard errors clustered by country are shown in parentheses. The use of ${ }^{* * *}$ denotes a coefficient significantly different from zero at the 0.01 confidence level; ${ }^{* *} 0.05 ;{ }^{*} 0.10$. Full sample includes all forecast vintages from WEO and MONA databases, covering 130 countries. Consensus Forecasts includes semiannual forecasts for 67 countries. 
In column 4, we restrict the sample to forecasts that ended up being most optimistic, with a value of $\hat{g}_{c, t+1}^{v}$ that is in the top quartile of the empirical distribution of forecast errors (that is, $\hat{g}_{c, t}^{v}>1.3$ ). Among this sample of optimistic forecasts, the coefficient on the credit-to-GDP gap remains 0.03 and is statistically significant at the 0.01 level. In addition, the share of loans denominated in foreign current becomes positively correlated with forecast optimism. In this sample, a one standard-deviation increase in the FX share (approximately 27 percentage points in this sample) is associated with an annualized growth forecast error that is 0.3 percentage points more optimistic.

We then investigate whether the forecast inefficiency result is limited to forecasts made in the official sector by the IMF, or is more generalized to forecasts made in the private sector. To do so, we estimate equation 3 on a sample of 2,056 semi-annual forecasts reported in Consensus Forecasts publications for 67 countries. We merge these vintages with information on control variables from the closest preceding GEE and WEO vintages. ${ }^{24}$ The result in column 5 is consistent with the baseline, despite the differences in country coverage across samples. We conclude that the inefficient use of financial information in growth forecasts is not confined to those made for IMF-supported programs, but applies to a variety of contexts and forecasters.

We then explore a possible channel through which financial vulnerabilities could result in larger forecast errors. If forecasts are preceded by a period of real exchange rate misalignment, financial vulnerabilities may cause exchange rate movements in subsequent years to have stronger impacts on growth, introducing a source of forecast errors if the forecaster has not properly modeled this mechanism. To test this, we introduce additional variables in the vector $\boldsymbol{X}_{c, t-1}^{v}$, including the change in the real effective exchange rate gap from $t-3$ to $t-1$, with the gap estimated as a percentage deviation from a one-sided five-year moving average to ensure that it was available at the time of the forecast. We also include an interaction between this variable and a dummy indicating that the lagged share of loans denominated in foreign currency is above the sample median.

Interestingly, column 6 shows that the recent evolution of the REER gap is positively correlated with forecast optimism, but only when liability dollarization is low. When liability dollarization is high, this relationship is completely negated. A possible interpretation of this result is that the prevalence of this particular financial vulnerability may draw the attention of the forecaster to an exchange rate misalignment, whereas a disruptive external imbalance receives less attention when liability dollarization is low. In any case, the significance of lagged credit developments remains unchanged.

In a final exercise, we study the role of banking crises in explaining growth forecast errors. ${ }^{25}$ To do so, we introduce two dummy variables. The first indicates that a banking crisis-as documented by Laeven and Valencia (2020) - took place in the two years prior to the forecast, and thus be thought to belong to $X_{c, t-1}^{v}$. The second indicates that a banking crisis took place in the two years following the forecast.

\footnotetext{
${ }^{24}$ Consensus Forecast surveys are available monthly for most countries and bi-monthly for others. To ensure the same data structure and forecast horizons as in the sample of WEO forecasts, we retain the two vintages per year whose survey dates correspond most closely to the timing of the Spring and Fall WEO vintages. Merging these datasets requires making an approximation in determining the precise information set-we take a conservative approach and use the most recent GEE vintage that precedes the date of the survey carried out by Consensus Economics for each vintage.

${ }^{25}$ We also estimated a specification in which we introduce a dummy variable if a country had undergone a Financial Stability Assessment Program (FSAP) engagement in the five years prior to the forecast. This was not found to affect the conditional mean of forecast errors, nor was its interaction with the credit-to-GDP gap variable statistically significant. As such, we do not find evidence that undertaking an FSAP mitigates the forecast inefficiencies documented in this section. Results are available upon request.
} 
Table 4. Robustness - Panel Forecast Efficiency estsT with Fixed Effects

\begin{tabular}{lccccc}
\hline & $(1)$ & $(2)$ & $(3)$ & $(4)$ & $(5)$ \\
\hline $\begin{array}{l}\text { Credit-to-GDP gap } \\
\text { (change from t-3 to } t-1)\end{array}$ & $0.03^{* * *}$ & $0.03^{* * *}$ & $0.03^{* * *}$ & $0.03^{* * *}$ & $0.03^{* * *}$ \\
& $(0.01)$ & $(0.01)$ & $(0.01)$ & $(0.01)$ & $(0.01)$ \\
Share of loans denom. FX & & & & & \\
$(t-1)$ & -0.00 & 0.00 & -0.00 & 0.00 & -0.00 \\
& $(0.00)$ & $(0.01)$ & $(0.00)$ & $(0.01)$ & $(0.01)$ \\
Dummy: Civil conflict & & & & & \\
& -0.14 & 0.29 & -0.11 & 0.28 & 0.25 \\
Exp. fiscal adjustment & $(0.25)$ & $(0.30)$ & $(0.25)$ & $(0.28)$ & $(0.32)$ \\
$(t-1$ to $t+2)$ & -0.01 & -0.02 & 0.02 & 0.02 & 0.00 \\
FE trade partners' growth & $(0.03)$ & $(0.03)$ & $(0.03)$ & $(0.03)$ & $(0.03)$ \\
$(t+1)$ & $0.50^{* * *}$ & $0.54^{* * *}$ & 0.09 & $0.17^{* *}$ & $0.19^{* *}$ \\
Ex post revision to real GDP & $(0.04)$ & $(0.04)$ & $(0.08)$ & $(0.08)$ & $(0.09)$ \\
$\quad(t-1)$ & 0.08 & -0.04 & 0.07 & -0.06 & 0.06 \\
Real GDP growth & $(0.07)$ & $(0.07)$ & $(0.07)$ & $(0.07)$ & $(0.09)$ \\
$(t-1)$ & $0.08^{* *}$ & $0.15^{* * *}$ & $0.05^{*}$ & $0.16^{* * *}$ & $0.16^{* * *}$ \\
& $(0.03)$ & $(0.03)$ & $(0.03)$ & $(0.03)$ & $(0.04)$ \\
Constant & & & & & \\
& -0.05 & -0.09 & $-1.68^{* * *}$ & $-1.50^{* * *}$ & $-0.96^{* *}$ \\
& $(0.14)$ & $(0.11)$ & $(0.39)$ & $(0.35)$ & $(0.44)$ \\
\hline Fixed Effects & & & & & \\
Observations & None & Country & Year & Country \& & Country \& \\
R-squared & & & & Year & Vintage \\
Time period & 3,799 & 3,799 & 3,799 & 3,799 & 3,799 \\
& 0.24 & 0.38 & 0.30 & 0.42 & 0.55 \\
& $2003-19$ & $2003-19$ & $2003-19$ & $2003-19$ & $2003-19$ \\
\hline
\end{tabular}

Notes: The dependent variable is $\hat{g}_{c, t+1}^{v}$, the forecast error for annualized growth of real output from $t-1$ to $t+1$. White heteroskedasticity-robust standard errors clustered by country are shown in parentheses. The use of $* * *$ denotes a coefficient significantly different from zero at the 0.01 confidence level; ${ }^{* *} 0.05 ;{ }^{*} 0.10$. Sample includes all forecast vintages from WEO and MONA databases, covering 130 countries.

In column 7, we show that the former is not significant, such that post-crisis forecasts are not conclusively more biased than others. The occurrence of crises during the forecast horizon is of course highly correlated with optimistic forecast errors, since such events are known to be difficult to anticipate. However, it is noteworthy that even after controlling for the occurrence of banking crises, the past evolution of the credit-to-GDP gap remains significantly correlated with forecast errors. That is, the information contained in this variable is informative for growth forecast errors outside of situations in which a banking crisis is triggered.

\section{ROBUSTNESS}

The dimensionality of the panel dataset used in this section allows us to undertake additional robustness tests that were not possible in the event study of Fund-supported programs presented in section 2. In Table 4, we report our baseline specification with the introduction of alternative vectors of fixed effects. In the first column, we reproduce the baseline result from Table 3, column 3, showing the estimate of equation 3 in the full sample of IMF forecasts. In columns 2 to 3 , we introduce country and year fixed effects, respectively. In column 4 , we introduce country and year fixed effects. And in column 5 , we introduce country and forecast vintage fixed effects. In all these specifications, the point estimate and standard error of the lagged credit-to-GDP gap variable are unaffected. 


\section{CONCLUSIONS AND POLICY IMPLICATIONS}

The previous literature has identified an optimism bias in certain samples of growth forecasts made by the IMF in the design of programs supported by the institution. Alternative explanations have been put forward for this inefficiency, including mistakes made in modeling the impact of fiscal policy adjustment on future growth. Our paper is the first to study the role of financial variables in explaining optimism in growth forecasts made in IMF-supported programs.

We find that commonly available financial variables are correlated with subsequent forecast errors made in the design of IMF-supported programs. Specifically, an expansion of the credit-to-GDP gap in the years preceding a program request is associated with a significantly more optimistic growth forecast for the next two years. This result is strongest among forecasts that were most optimistic, where errors are also increasing in the economy's degree of liability dollarization.

These results are indicative that the IMF's program growth forecasts do not efficiently incorporate information found in observable financial variables. This may reflect deficiencies in the macrofinancial modeling that underpins program design. We test whether this inefficiency result reflects the endogenous calibration of monetary and financial policies in response to credit conditions, and find that it does not.

While we show that the inefficient use of financial variables is strongest among growth forecasts made in the context of Fund-support programs, we document similar inefficiencies in growth forecasts produced in the IMF's surveillance activities, as well as in forecasts made by professional forecasters in the private sector. We posit that a likely mechanism behind this result is the inherent difficulty in distinguishing in real time between an ongoing credit expansion that is structural-reflecting a process of financial development-from a cyclical boom. Additional research is needed into distinguishing these credit dynamics in real time, and developing models of their short-term macroeconomic implications that could better inform growth forecasts. 


\section{REFERENCES}

Adrian, Tobias, Nina Boyarchenko, and Domenico Giannone, 2019. "Vulnerable Growth," American Economic Review 109(4): 1263-89.

An, Zidong, João Tovar Jalles, and Prakash Loungani, 2018. "How Well Do Economists Forecast Recessions?" International Finance 21(2): 100-21.

Beaudry, Paul and Tim Willems, 2021. "On the Macroeconomic Consequences of Over-Optimism,"American Economic Journal: Macroeconomics, forthcoming.

Blanchard, Olivier and Daniel Leigh, 2013. "Growth Forecast Errors and Fiscal Multipliers," AEA Papers and Proceedings 103(3): 117-20.

Carrière-Swallow, Yan and Luis Felipe Céspedes, 2013. "The Impact of Uncertainty Shocks in Emerging Economies," Journal of International Economics 90(2): 316-25.

Carrière-Swallow, Yan, Antonio C. David, and Daniel Leigh, 2021. "Macroeconomic Effects of Fiscal Consolidation in Emerging Economies: New Narrative Evidence from Latin America and the Caribbean," Journal of Money, Credit and Banking 53(6): 1313-35.

Chen, Sophia and Romain Rancière, 2019. "Financial Information and Macroeconomic Forecasts," International Journal of Forecasting 35: 1160-74.

Claessens, Stijn, M. Ayhan Kose, and Marco E. Terrones, 2009. "What Happens during Recessions, Crunches and Busts?" Economic Policy 24(60): 653-700.

Díaz-Alejandro, Carlos F., 1985. "Good-bye Financial Repression, Hello Financial Crisis," Journal of Development Economics 19(1-2): 1-24.

Eicher, Theo S., David J. Kuenzel, Chris Papageorgiou, and Charis Christofides, 2019. "Forecasts in Times of Crises," International Journal of Forecasting 35: 1143-59.

Ho, Giang and Paolo Mauro, 2016. "Growth: Now and Forever?" IMF Economic Review 64(3): 526-47.

Högbladh, Stina, 2021. "UCDP GED Codebook version 21.1," Department of Peace and Conflict Research, Uppsala University.

International Monetary Fund, 2019. "Review of Program Design and Conditionality," IMF Policy Paper 19/012, April. Washington, DC.

International Monetary Fund, 2021a. "2021 Comprehensive Surveillance Review—Overview Paper," IMF Policy Paper 21/027, April. Washington, DC.

International Monetary Fund, 2021b. "2021 Comprehensive Surveillance Review—Background Paper on Systemic Risk and Macroprudential Policy Advice in Article IV Consultations," IMF Policy Paper 2 1/033, May. Washington, DC. 
Ismail, Kareem, Roberto Perrelli, and Jessie Yang, 2020. "Optimism Bias in Growth Forecasts-The Role of Planned Policy Adjustments," IMF Working Paper 20/229. Washington, DC: International Monetary Fund.

Kim, Jun I., Jean-Marc B. Atsebi, Kwang Y. Lee, Hasan H. Toprak, and Jiakun Li, 2021. "CrossCountry Analysis of Program Design and Growth Outcomes: 2008-19," IEO Background Paper BP/21-01/01. Washington, DC: Independent Evaluation Office of the International Monetary Fund.

Kirti, Divya, 2018. "Lending Standards and Output Growth," IMF Working Paper 18/23. Washington, DC: International Monetary Fund.

Laeven, Luc and Fabián Valencia, 2020. "Systemic Banking Crises Database II," IMF Economic Review 68: 307-61.

Loungani, Prakash, 2001. "How Accurate Are Private Sector Forecasts? Cross-Country Evidence from Consensus Forecasts of Output Growth," International Journal of Forecasting 17: 419-32.

Musso, Alberto and Steven Phillips, 2002. "Comparing Projections and Outcomes of IMF-Supported Programs," IMF Staff Papers 49(1): 22-48.

Sundberg, Ralph and Erik Melander, 2013. "Introducing the UCDP Georeferenced Event Dataset," Journal of Peace Research 50(4): 523-32.

Timmermann, Allan, 2007. "An Evaluation of the World Economic Outlook Forecasts," IMF Staff Papers 54(1): 1-33. 